\title{
RELATIONSHIP BETWEEN THE TYPE OF LABOUR AND BREASTFEEDING ATTACHMENT (LATCH-ON) AND BREAST ENGORGEMENT INCIDENCE IN POSTPARTUM MOTHERS
}

\author{
Minta Rasi Marito ${ }^{1}$, Tuti Asrianti Utami ${ }^{1}$, Wilhelmus Susilo ${ }^{1}$ \\ Sint Carolus School Health of Sciences \\ Corresponding email: tutichaidir18@gmail.com
}

\begin{abstract}
Breast engorgement is one of the common problems that occur in the postpartum period. Inappropriate latch on would cause several problems including, baby's sucking uneffective, cracking nipple, breastmilk production is not maximal, and finally, the breast becomes engorgement. This study aimed to determine the relationship between the type of labor and breastfeeding latch-on and the breast engorgement incidence in the postpartum period. An observational study, the descriptive quantitative study, and cross-sectional approaches were applied, the study has been done from April to July 2018. Purposive sampling technique was used to select one hundred and two postpartum participants. The questioner, latch assessment tool, and assessment tool for observation were used in this study. The data were analyzed using chi-square, Kendall's tau b, and Kendall's tau c. The type of the delivery (pvalue :0,001), and Breastfeeding attachment (p-value:0,001) had relationship with breast engorgement incidence in postpartum period. This study also showed that age ( $\mathrm{p}$-value:0,331), educational level ( $\mathrm{p}$-value:0,532), and parity (p-valuee:0,056) were no relationship with breast engorgement incidence. It is expected from this study to increase the knowledge and independence of postpartum women about latch on to prevent breast engorgement. The future research would be able to study about mother's knowledge and motivation, family and health professional's support, postpartum stress, and early breastfeeding initiation in the surgery room.
\end{abstract}

Keywords: Breast engorgement, latch on, types of delivery.

\section{INTRODUCTION}

Mother's milk (ASI) is the best nutrition for babies, breast milk contains nutrients needed by babies during the first six months of life. The Sustainable Development Goals (SDGs) establish breastfeeding as one of the keys to reach 17 in 2030 (Saputra, 2016). WHO and UNICEF, in 2017 say the average rate of exclusive breastfeeding in the world is $40 \%$, this figure is still far from the target of $70 \%$ in 2030 . The Ministry of Health of the Republic of Indonesia in 2017 says the coverage of breastfeeding in Indonesia in 2016 is $0-5$ month is $54.0 \%$, while infants given ASI up to six months are $29.5 \%$.

Breastfeeding is a natural activity of postpartum women, but women are at risk of facing various obstacles. Abuidhail's study (2017) says that postpartum women 30 days after labor during breastfeeding such as a nipple crack, experienced $32 \%$ of women. This might be due to improper breastfeeding techniques, breast swelling, cesarean section, use of milk bottles, and mother's level of education. Wulandari and Handayani (2011) said that postpartum mothers often experience problems in exclusive breastfeeding, including because of the production of breast milk that is not optimal. 
Minta Rasi Marito: Relationship between The Type of Labour and Breastfeeding Attachment (Latch-on)

Akter et al (2016) study said that out of 114 breastfeeding mothers, 63.5\% managed to give exclusive breastfeeding. A common problem in nursing mothers is $46.49 \%$ of mothers feel that breast milk is not enough, $20.17 \%$ of attachments are not good, $17.5 \%$ of breast is swollen, and $7.89 \%$ of nipples are blistered, $2.63 \%$ of nipples are immersed, $1.75 \%$ of nipples are sore, and $0.877 \%$ abscess in the breast. Swollen breasts are usually followed by a strained areola because the amount of milk that begins to form, this makes it difficult for the baby to attach so that the baby's milk is not optimal (Mangesi, 2016).

Attachment or latch on is the placement of the baby's mouth on the nipple, areola, and breast, with the position of the chin attached to the breast so that adequate breast milk expenditure. Preparation for attachment at the beginning of breastfeeding, the mother ejects milk or a little colostrum and is applied to the nipples, putting the baby facing the mother's breast (Perry et al, 2014). WHO 2011 says the correct attachments are: 1) Areola looks more above baby's mouth, 2) Baby's mouth is wide open, 3) Baby's lower lip folds out, 4) Baby's chin is attached to the breast, 5) Baby's cheeks are rounded or face to face mother's breast. Whereas the attachment is incorrect, ie the baby only suckles in the nipple which will cause the baby to only get a little milk because the baby's gums do not press on the lactiferous sinuses, and the mother will feel pain (Qonitun, 2012).

Breastfeeding attachment was assessed using the Latch Assessment tool (Kenner and Lott, 2014) with the criteria assessed being Latch, Audible Swallowing, Type of nipple, Comfort of the mother, and Hold or positioning. Hasanah, Hardiani, and Susumaningrum (2017) say that the attachment of babies to the mother's breasts is good and appropriate to reduce the problem of breastfeeding because breastfeeding babies reach the areola. Anggraeni (2016) says that attachment is significantly associated with breast swelling, p-value 0,000, incorrect position of the baby's head causes the baby's suction is not optimal, nipple blisters and risk of breast swelling.

Swollen breasts have an impact on breast milk is difficult to get out, there is the pressure of breast milk in the breast, or oxytocin reflexes that do not work properly (WHO, 2011). Breast swelling drastically changes and the volume of breast milk increases significantly on days 3-5 in the puerperium (Perry et al., 2014). When milk production increases rapidly, the volume may exceed the storage capacity of the alveoli in the breast. If milk is not released, the alveoli will enlarge, causing a decrease in capillary blood flow. The blood vessels become more congested, fluid seeps into the surrounding tissue, resulting in edema. The breasts become tight, hot, the areola becomes hard, and the nipple becomes flat, so the baby has difficulty sticking to the breast. Because of the backpressure in the full mammary gland, it inhibits milk production, if breast milk is not removed from the breast, the supply of breast milk can be reduced (Perry et al, 2014). 
Minta Rasi Marito: Relationship between The Type of Labour and Breastfeeding Attachment (Latch-on)

2011 WHO said there was a difference between full breasts and swollen breasts. The breasts are said to be swollen characterized by The breasts are painful, edema, strained especially on the nipples, appear red spread, breast milk does not come out but drips, and fever for 24 hours. The breasts are said to be full if: the breast feels hot, heavy, hard, the milk flows, and there is no fever.

According to WHO (2011), swollen breasts are conditions where breastmilk is difficult to be produced because of the pressure of breastmilk in the breast, or due to oxytocin reflexes that do not work well. Breast swelling occurs due to excessive breastmilk (hyperlactation), late breastfeeding, poor attachment, incomplete emptying of breast milk, schedule and duration of breastfeeding, small breast size, did not breastfeeding at night, stressed mothers, given supplements, fatigue mothers, mothers get intravenous fluids during labor (Hesti KY, 2017; Novita, 2011). Anggraeni's research, (2016) stated that out of 359 postpartum mothers in Jakarta X Hospital, 130 or $36.21 \%$ experienced breast swelling. Statistical data on maternity care at Hospital X Jakarta in June-October 2017 from 598 postpartum mothers recorded 174 or $29 \%$ experienced breast swelling during the treatment period. However, limited information about the relationship between breast attachment and breast swelling. This study aims to determine the relationship of attachment to breastfeeding with the incidence of swollen breasts in postpartum mothers.

\section{METHODS}

This study used an observational research method with a descriptive correlation research design. The cross-sectional approach was applied to find the relationship between variables of age, education, parity, type of delivery, and attachment to breastfeeding with the incidence of breast swelling by measuring and collecting at the same time.

The population in this study were all postpartum mothers who were treated for 3 days in the puerperium with criteria for having a baby and performing breastfeeding. The sample of 102 postpartum mothers was selected using purposive sampling. The study was conducted in the maternity room of X Hospital Jakarta in April-July 2018. The research instrument used in the form of a questionnaire and observation guidelines consisted of 1) Questionnaire A, questions about the characteristics of postpartum mothers include education, age, parity, and type of childbirth, 2) Questionnaire B, the results of researchers 'observations of latch on breastfeeding on the first day, and 3) Questionnaire C, the results of researchers' observations of the condition of the puerperal breast on the third day of delivery. This study uses an observation sheet to assess the condition of the breasts of Hill and Humenick, 1994; Brown and Langdon, 2014). 
Minta Rasi Marito: Relationship between The Type of Labour and Breastfeeding Attachment (Latch-on)

\section{RESULTS}

1. Univariate Analysis

Table 1. Responden's Characteristic

\begin{tabular}{|c|c|c|c|c|}
\hline No & Characteristic & & $\begin{array}{l}\text { Total } \\
\mathrm{N}\end{array}$ & $\begin{array}{l}\text { Percentase } \\
\%\end{array}$ \\
\hline \multirow{3}{*}{1} & \multirow{3}{*}{ Age } & $<20$ years old & 0 & 0 \\
\hline & & $\mathbf{2 0}$ - $\mathbf{3 5}$ years old & 91 & 89.2 \\
\hline & & $>35$ years old & 11 & 10.8 \\
\hline \multirow{3}{*}{2} & \multirow{3}{*}{ Education } & Elementary School & 0 & 0 \\
\hline & & Middle School & 7 & 6.9 \\
\hline & & College & 95 & 93.1 \\
\hline \multirow{3}{*}{3} & \multirow{3}{*}{ Parity } & Primipara & 53 & 52 \\
\hline & & Multipara & 49 & 48 \\
\hline & & Grandemultipara & 0 & 0 \\
\hline \multirow[b]{2}{*}{4} & \multirow[b]{2}{*}{ Labor Type } & Pervaginam & 42 & 41.2 \\
\hline & & Sectio Cesarea & 60 & 58.8 \\
\hline \multirow{3}{*}{5} & \multirow{3}{*}{$\begin{array}{l}\text { Breastfeeding } \\
\text { Attachment }\end{array}$} & Good & 27 & 26.5 \\
\hline & & Moderate & 74 & 72.5 \\
\hline & & Less & 1 & 1 \\
\hline \multirow{2}{*}{6} & \multirow[t]{2}{*}{$\begin{array}{l}\text { Breast } \\
\text { Condition }\end{array}$} & Swollen & 32 & 31.4 \\
\hline & & Not Swollen & 70 & 68.6 \\
\hline
\end{tabular}

Table 1 explains that the majority of respondents aged 20-35 years were 91 respondents (89.2\%), the tertiary level of education was 95 respondents $(93.1 \%)$, primipara as many as 53 respondents (52\%), types of delivery with cesarean section as many as 60 respondents $(58.8 \%)$, breastfeeding attachments were moderate as many as 74 respondents $(72.5 \%)$, and the breast condition of respondents on the third day after giving birth mostly did not experience swelling breast events as many as 70 respondents (68.6\%). 
Minta Rasi Marito: Relationship between The Type of Labour and Breastfeeding Attachment (Latch-on)

2. Bivariate Analysis

Table 2. Relationship between Swelling Equity and Breast Occurrence

\begin{tabular}{|c|c|c|c|c|c|c|c|}
\hline \multirow[t]{3}{*}{ Characteristic } & \multicolumn{4}{|c|}{ Breast Condition } & \multicolumn{2}{|c|}{ Total } & \multirow[t]{3}{*}{ P-Value } \\
\hline & \multicolumn{2}{|c|}{ Swollen } & \multicolumn{2}{|c|}{ Not Swollen } & \multirow[b]{2}{*}{$\mathrm{N}$} & & \\
\hline & $\mathrm{N}$ & $\%$ & $\mathrm{~N}$ & $\%$ & & $\%$ & \\
\hline \multicolumn{8}{|l|}{ Parity } \\
\hline Primiparitas & 21 & 39.6 & 32 & 60.4 & 53 & 100 & 0.056 \\
\hline Multiparitas & 11 & 22.4 & 38 & 77.6 & 49 & 100 & \\
\hline $\begin{array}{l}\text { Labor Type } \\
\text { Pervaginam }\end{array}$ & 6 & 14.3 & 36 & 85.7 & 42 & 100 & \multirow[t]{2}{*}{0.001} \\
\hline Sectio Cesarea & 26 & 43.3 & 34 & 56.7 & 60 & 100 & \\
\hline \multicolumn{8}{|l|}{ Attachment } \\
\hline Good & 3 & 11.1 & 24 & 88.9 & 27 & 100 & \multirow{3}{*}{0.001} \\
\hline Moderate & 28 & 37.8 & 46 & 62.2 & 74 & 100 & \\
\hline Less & 1 & 100 & 0 & 0.0 & 1 & 100 & \\
\hline
\end{tabular}

Table 2 explains that respondents with cesarean section delivery who experienced swollen breasts were 26 respondents $(43.3 \%)$. Chi-square test results showed that there was a relationship between the type of labor and the incidence of swollen breasts in X Hospital Jakarta (P-value $=0.001 ; \alpha=0.05)$. Table 2 explains that respondents with moderate value attachments who experienced swollen breasts were 28 respondents $(37.8 \%)$. The results of the Kendall's test $\mathrm{c}$ found that there was a relationship between breastfeeding attachment and the incidence of swollen breasts in Jakarta X Hospital (P-value $=0.001 ; \alpha=$ $0.05)$.

\section{DISCUSSION}

Research shows that mothers with cesarean section experience more breast problems compared to mothers with vaginal delivery. Cesarean section causes delays in breastfeeding, inappropriate breastfeeding due to pain, and increased problems in infants such as premature and TTN (transient tachypnea of the newborn). The results of this study are in line with the research of Boskabadi, et al (2014), that the type of labor has a significant relationship with the emergence of postpartum breast problems with P-value 0.007. However, it is different from Anggraeni's research (2016) that there is no correlation between the type of labor and the incidence of swollen breasts in postpartum mothers with P- 
Minta Rasi Marito: Relationship between The Type of Labour and Breastfeeding Attachment (Latch-on)

value 0.640. Cesarean delivery faces a longer recovery period after surgery (incisional wound pain, anesthetic effect) compared to vaginal delivery respondents, so respondents with cesarean section experience difficulty in positioning the baby in the breastfeeding process. These conditions cause the mother to feel anxious about the health of herself and her baby. Anxiety experienced by the mother triggers the release of adrenaline which causes vasoconstriction in the veins of the alveoli, this will inhibit the letdown reflex so that the milk does not flow and the ASI dam occurs. Respondents with cesarean section require longer recovery so that the breastfeeding and attachment process is not optimal in the first days. Respondents also tended to be more sleepy, sick, and more focused on recovery.

The results of this study are in line with the research of Astuti and Kurniawati (2011) that of 11 respondents with how to breastfeed less correctly 9 or $81.86 \%$ of them experienced a swollen breast incidence, 22 respondents with correct breastfeeding 2 or $9.1 \%$ of them experienced breast events swollen. Swollen breast events occur because breast milk is not adequately removed and the position of the wrong baby while breastfeeding. Hasanah, Hardiani, and Susumaningrum (2017) say that proper breastfeeding attachment will reduce the occurrence of problems in the breastfeeding process because the baby feeds to the areola.

The occurrence of swollen breasts can be prevented by adhering to moderate to good breastfeeding so that the emptying of breast milk is maximal. Sticking with the areola looks more above the baby's mouth than under it, the mouth is wide open, the baby's lips are folded out, the chin is attached to the breast, and the baby's cheek is rounded or facing the mother's breast is the key to successful breastfeeding. Incorrect attachments will cause sores and pain in the nipple, breast milk cannot be effectively removed so that the breast becomes swollen.

\section{CONCLUSION}

Post-cesarean cesarean women experience pain from the former incision, so the mother delays the breastfeeding process and the baby is not responsive to suckling. This pain supports the mother not to breastfeed her baby, the milk will accumulate in the breast and cause swollen breasts. Mothers also have difficulty putting and positioning the baby properly while breastfeeding. The correct breastfeeding position is attempted by the mother to hold her baby calmly, the baby's body in a straight line, the baby facing the breast, the mother holding the baby tightly, so the baby can suck easily, this position helps good breastfeeding.

A good attachment to breastfeeding will help the mother to produce breast milk to the fullest. Bad attachments can make a mother look as if she is not producing enough milk or the mother has a poor 
Minta Rasi Marito: Relationship between The Type of Labour and Breastfeeding Attachment (Latch-on)

supply of breast milk. For this reason, mothers need practical assistance from nurses who have the knowledge and skills to provide support for breastfeeding activities.

Suggestions are increasing nurses' knowledge and skills about breastfeeding attachment and overcoming swollen breasts in postpartum mothers, especially in Caesarean section, providing education about correct breastfeeding attachments before delivery, learning to become lactation counselors, adding literature or references to the development of science especially in the field of maternity care. The next study was research on maternal knowledge about lactation management, motivation, support (family, and health workers) in breastfeeding, stress on postpartum mothers, and IMD in women with cesarean section

\section{REFERENCES}

Abbas, I. M. (2015). Assessment of LATCH Tool Regarding Initiation of Breastfeeding among Women after Childbirth. 5(05).

Abuidhail, J. O. (2017). Evaluation of postnatal education on breastfeeding technique of Jordanian mothers. . British Journal of Midwifery, 25(11), 715-722.

Akter, S. T. (2016). A Study on post partum breast problems of mothers attending at lactation management center (LMC). . Bangladesh Medical Journal, 44(3), 136-139.

Anggraeni, S. (2016). Faktor-Faktor yang Berhubungan dengan Terjadinya Pembengkakan Payudara pada Ibu Post Partum di Rumah Sakit X. . ejournal-stik-sintcarolus.

Astuti, I. D. (2011). Analisa Hubungan Pengaruh Cara Menyusui dengan Kejadian Payudara Bengkak pada Ibu Post Partum. Jurnal Kebidanan, 3(1).

Boskabadi, H. R. (2014). Risk factors of breast problems in mothers and its effects on newborns. Iranian Red Crescent Medical Journal, 16(6).

Brown, D. \&. (2014). Does Kinesio Elastic Therapeutic Taping Decrease Breast Engorgement in Postpartum Women. Clinical Lactation. 5(2), 67-74.

$\mathrm{Fu}$, J. C. (2011). Factors influencing breast symptoms in breastfeeding women after cesarean section delivery. . Asian nursing research, 5(2), 88-98.

Hasanah, A. I. (2017). Hubungan Tekhnik menyusui dengan risiko terjadinya mastitis pada ibu menyusui di desa Kemuning Kecamatan Arjasa Kabupaten Jember. . e-journal pustaka kesehatan, 5.

Hesti, K. Y. (2017). Effect of Combination of Breast Care and Oxytocin Massage on Breast Milk Secreation in Postpartum Mothers. Belitung Nursing Journal, 3(6), 784-790.

Kenner, C. \&. (2014). Comprehensive Neonatal Nursing care. Fifth Edition. Springer Publishing Company.

Mangesi, L. \&. (2016). Treatment for breast engorgement during lactation (Review). 
Minta Rasi Marito: Relationship between The Type of Labour and Breastfeeding Attachment (Latch-on)

Novita, R. V. (2011). .Efektifitas paket "Bunda Ceria" terhadap rasa nyeri dan pembengkakan payudara serta produksi ASI pada ibu post partum di Jakarta.

Perry, S. E. (2014). Maternal Child Nursing Care . Elsevier.

Qonitun, U. (. (2018, Maret 25). Gambaran perilaku ibu dalam menyusui terhadap bendungan ASI pada ibu nifas di Polindes Barokah Kecamatan Jatirogo kabupaten Tuban. . Retrieved from http://lppm.stikesnu.com/wp-content/uploads/2014/02/3-Umu-Qonitun.pdf.

Saputra, Y. (2016, Agustus 07). Retrieved from Pekan Asi Sedunia:Angka Pemberian ASI di Indonesia masih rendah.: https://www.rappler.com/indonesia/142238-pekan-asi-sedunia-indonesia-masih rendah:

Sastri, N. (2016). Analisis Kejadian Payudara Bengkak Pada Ibu Nifas Di Bidan Praktik Mandiri Maliah Palembang .

UNICEF, W. \&. (2017). Global Breastfeeding Scorecard Tracking. Progress for Breastfeeding Policies and Programmers. .

WHO. (2011). Pelatihan konseling menyusui modul 40 jam. UNICEF.

Wulandari, S. R. (2011). Asuhan kebidanan ibu masa nifas. . Gosyen Publishing. 